\title{
Commentary
}

\section{Why Students Should Seek an Internship with SpaceX Amid the COVID-19 \\ Pandemic and What to Expect}

Melissa Layne

American Public University System

\section{Introduction}

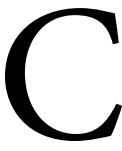

OVID-19 has left global economies struggling as they continue to enact strict measures to slow the pandemic from spreading. Despite many industries making an abrupt but successful transition from face-to-face to virtual, home-based work environments, many others have not been as fortunate and are barely keeping their businesses afloat. There is one industry, however, that is doing an exceptional job of weathering the economic turmoil-the space industry.

Even pre-COVID-19, the space industry had a strong track-record of attracting interest from the investment community. Investment banks including Morgan Stanley, Goldman Sachs and Bank of America Merrill Lynch expect the space industry to grow to over \$1 trillion by 2040 (Palerm, 2019). However, in their 2019 report Global Satellite Capacity Supply and Demand, $16^{\text {th }}$ Edition, Northern Sky Research (NSR) predicts that the resulting revenues will be modest. They report that when combining Satcom capacity, satel- lite manufacturing, launch and ground equipment, the $\$ 1$ trillion projection is highly achievable, but perhaps may take longer (NSR, 2019), yet perhaps not.

\section{COVID-19 and the Immediate Need for Broadband}

T ife has changed drastically since the NSR's June 2019 report. The Coronavirus pandemic and mandatory self-isolation restrictions to control its spread have triggered the overwhelming demand for broadband Internet.

There are a few low-earth orbit satellite providers such as Amazon's Project Kuiper and Telesat's LEO satellite constellation, however, they are all several years behind in even possibly offering customers high-speed Internet service. Another provider, OneWeb, recently filed for bankruptcy. Leading in both production and satellite launches is Elon Musk's Starlink (Mack, 2020), which to date has launched 240 satellites and expects to offer Internet globally sometime in 2021 (Cooke, 2020). SpaceX's lead manufacturing engineer for Starlink, Jessica Anderson, states 
"The design goal for Starship is three flights per day on average [per ship], which equates to roughly 1,000 flights per year at greater than 100 tons per flight. This means every 10 ships would yield 1 megaton per year to orbit. This is a significant effort, and we are looking for highly skilled engineers and welders to help us make this a reality." (Mazumdar, 2020)

SpaceX's success has strategically positioned them as a leader in the aerospace and satellite industry. Despite COVID-19, SpaceX has been spared from being forced to cut salaries or lay off employees. Conversely, SpaceX con- tinues to hire. Additionally, this success will likely to continue should the dependency upon their ships and satellites continue.

\section{The Need for Space Professionals}

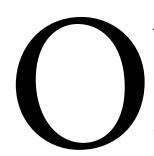
verall, the space industry will continue to fill increasing job positions in both the private and military sectors and diverse educational and training opportunities for the next-generation of space professionals will also be required. Table 1 presents education, experience, and training typically required for space-related occupations (Angeles and Vilorio, 2016).

Table 1. Education, experience, and training typically required for space

\begin{tabular}{|c|c|c|c|}
\hline \multirow{2}{*}{ Occupation } & \multicolumn{2}{|c|}{ Typically needed to enter the occupation } & \multirow{2}{*}{$\begin{array}{c}\text { Typically needed to attain } \\
\text { competency in the occupation } \\
\text { On-the-job training }\end{array}$} \\
\hline & Education & $\begin{array}{l}\text { Work experience in a } \\
\text { related occupation }\end{array}$ & \\
\hline \multicolumn{4}{|l|}{ Scientists } \\
\hline Astronomera & $\begin{array}{r}\text { Doctoral or } \\
\text { professional } \\
\text { degree }\end{array}$ & None & None \\
\hline $\begin{array}{l}\text { Atmospherle and apace } \\
\text { aclentlata }\end{array}$ & Bachelar's degree & None & None \\
\hline Phyalclata & $\begin{array}{l}\text { Doctoral or } \\
\text { professional } \\
\text { degree }\end{array}$ & None & None \\
\hline \multicolumn{4}{|l|}{ Engineers } \\
\hline Aarospace anginears & Bachelor's degree & None & Mone \\
\hline Computer hardware engineers & Bachelar's degree & None & None \\
\hline Electronles engineers ${ }^{(1)}$ & Bachelor's degree & None & None \\
\hline Mechanical engineera & Bachelor's degrae & None & None \\
\hline \multicolumn{4}{|l|}{ Technicians } \\
\hline $\begin{array}{l}\text { Aerospace engineering and } \\
\text { operations technicians }\end{array}$ & $\begin{array}{r}\text { Associate's } \\
\text { degree }\end{array}$ & None & None \\
\hline Avlonics techniclans & $\begin{array}{r}\text { Associate's } \\
\text { degree }\end{array}$ & None & None \\
\hline $\begin{array}{l}\text { Life, physical, and aocial } \\
\text { gclence tachnielana, all other }(\underline{2})\end{array}$ & $\begin{array}{r}\text { Acsociate's } \\
\text { degree }\end{array}$ & None & None \\
\hline \multicolumn{4}{|l|}{ Medla and communlcationa } \\
\hline Photographars & $\begin{array}{l}\text { High school } \\
\text { diploma or } \\
\text { equivalent }\end{array}$ & None & Long-term on-the-job training \\
\hline Producers and directors & Bachelar's degrae & Less than 5 years & Nione \\
\hline Public relations speclallsta & Bachelar's degree & None & None \\
\hline Technícal writera & Bachelor's degree & Less than 5 years & Short-term on-the-job training \\
\hline \multicolumn{4}{|c|}{$\begin{array}{l}\text { Footnotes: } \\
\text { (1) Excludes computer anginears. } \\
\text { (2) Includes includes meteorological aides. } \\
\text { Source: U.S. Bureau of Labor Statistics }\end{array}$} \\
\hline
\end{tabular}


In addition to a space studies program, gaining on-the-job experience with an internship is one of the best ways to jump-start a new career.

\section{Internships}

B ecause there are a number of career pathways in the space industry (as shown in Table 1), there exist several internship opportunities with organizations, government, and private companies. Internships are a wonderful way to gain experience, learn from mentors, connect with other interns, and hone valuable skills that provide an added advantage to a student close to graduating, or a recent post-grad. In addition to continually hire, SpaceX also offers an internship to graduate students and recent post-grads who are eager to embark on a space career.

\section{The SPACE-X Internship Program}

7 he SpaceX Internship is a yearround program offered in the Spring (Jan - Apr), Summer (May-Aug), and Fall (Sept-Dec) with opportunities to play a direct role in transforming space exploration and helping realize the next evolution of humanity as a multi-planetary species.

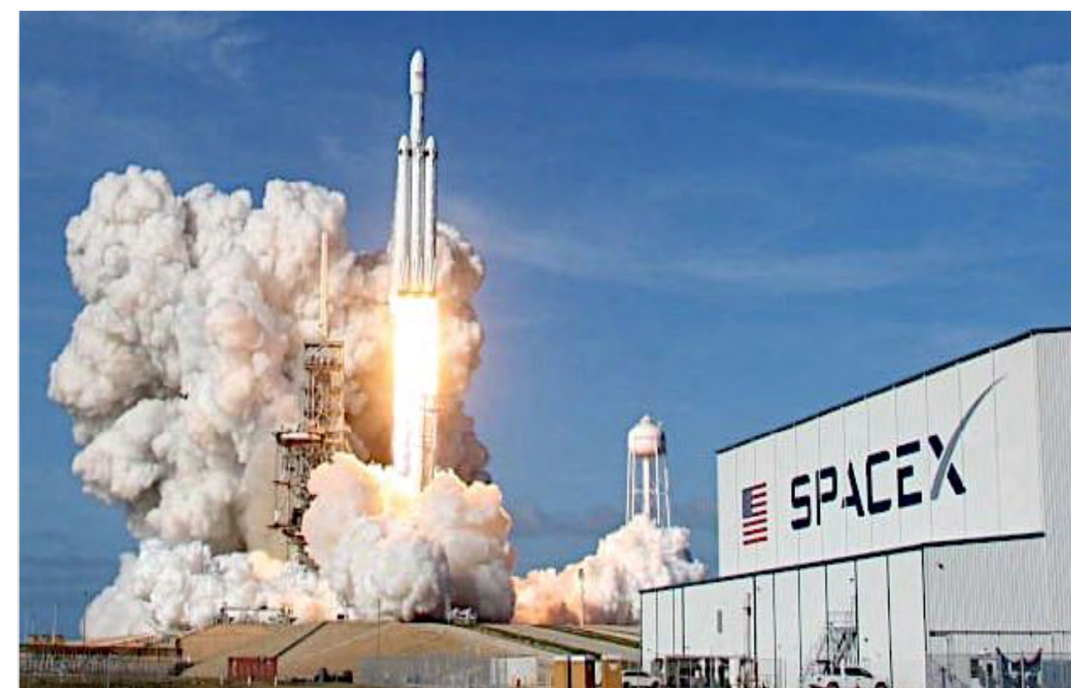

Figure 1. SpaceX headquarters in Hawthorne, California

Opportunities are available across all engineering functions and business operations at various locations including:

- McGregor, TX - Rocket development facility

- Cape Canaveral, FL - Launch site

- Vandenberg AFB, CA - Launch site

- Hawthorne, CA - Headquarters 
- Seattle, WA - Satellite development

- Washington, DC - Government affairs

They do not exclusively recruit from certain schools, but rather, they seek the most talented candidates for their advanced Intern Program and entry-level full time positions that have a history of significant contributions to hands-on extracurricular projects, in addition to a strong academic record. Technical interns and associate engineers are involved in student-driven engineering groups in school, that focus on designing, building, testing, and/ or coding. For interns in non-technical roles, they look for similar hands-on project experience in their respective fields. Internships and associate engineer opportunities at SpaceX are paid, and can also be used to satisfy course credit at the discretion of the student's university.

\section{Take it From a SpaceX Intern- Here's What They Have to Say}

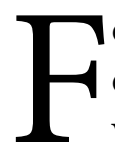
or both internship and associate engineer positions, students learn valuable hands-on experiences. The most successful candidates for SpaceX's Intern Program have a history of significant contributions to handson extracurricular projects in addition to a strong academic record. This is not an ordinary "internship" - students are given as much responsibility as regular full-time engineers and are an important part of the team.

Here are some interns, past and present, who share their thoughts on working at SpaceX.

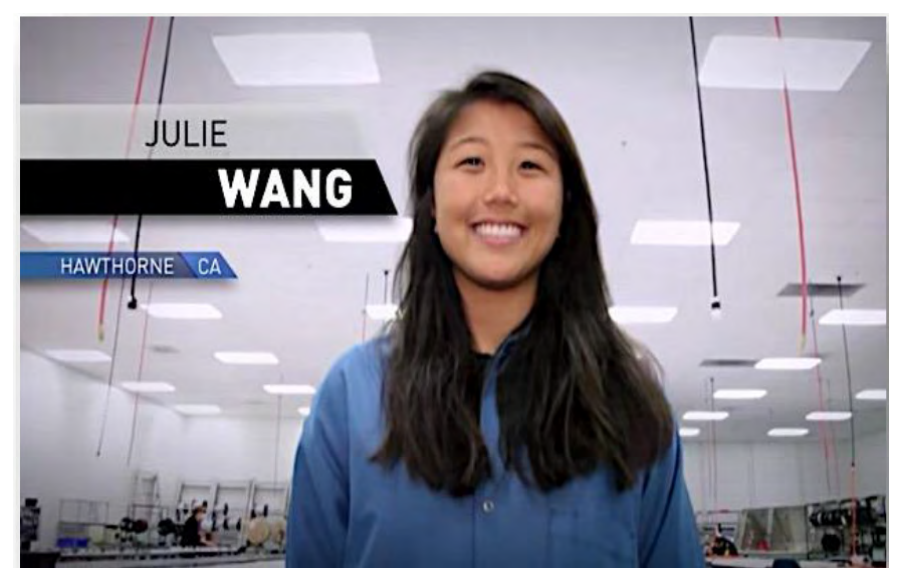

Julie Wang: "I'm an intern with avionics right now I'm working on a receiver for the Dragon and in order to navigate dragon communicates with Tigress which is a sub-satellite that NASA sent up. Specifically, I'm working on the receiver that goes on Dragon that will link up to those satellites [to] figure out where the capsules will fit and then navigate." 


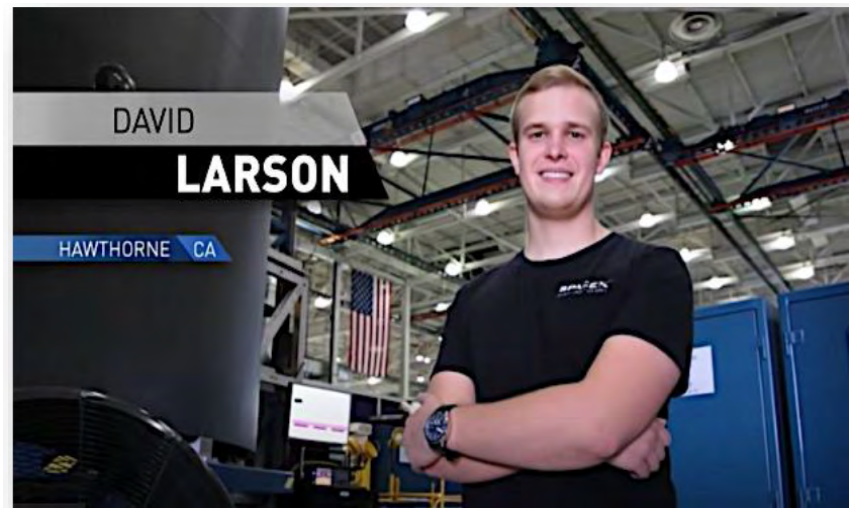

David Larson: "I'm in the structure department here at SpaceX. Spacex is pretty awesome. It's an incredible place to work. You get to do things that you don't get to do anywhere else, and as an intern you get to work on it. You don't have to be a full-time engineer to work on technologies and projects that are pushing the boundaries in Space Flight."

Joshua Mann: "I work in propulsion. I have programming computer tasks which pretty much is how we determine whether or not our engines are operating to the right specifications. I'll do a lot of analysis on the different devices that you'll use to test them and make sure that they're running in the correct

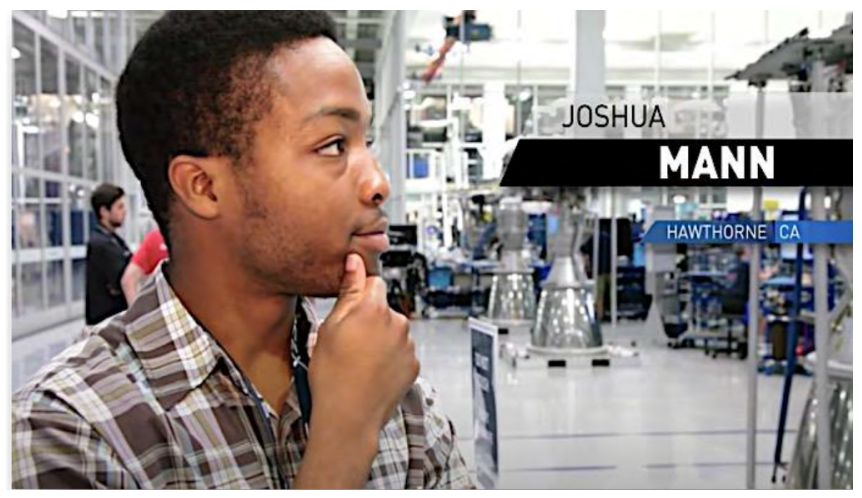
fashion."

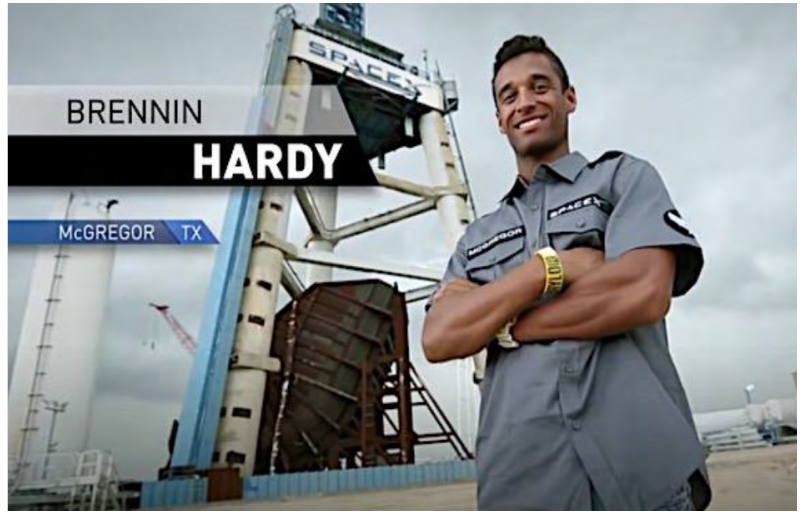

Brendan Hardy: "I work with ground support equipment engineering in McGregor, Texas. We're really more hands-on get-it-done sort of team. I've learned a ton-especially what we do in ground support equipment. I could take what I've learned and I could go to an oil field, I could go to another aerospace industry. I could go pretty much anywhere with all the stuff that I've learned." 
Jeff Ellenoff: “I'm a test engineer focusing on Dragon development. I get to come to work and play with spaceships day. What person wouldn't want to do that? When an engine test happens it's the most incredible thing you could possibly think of."
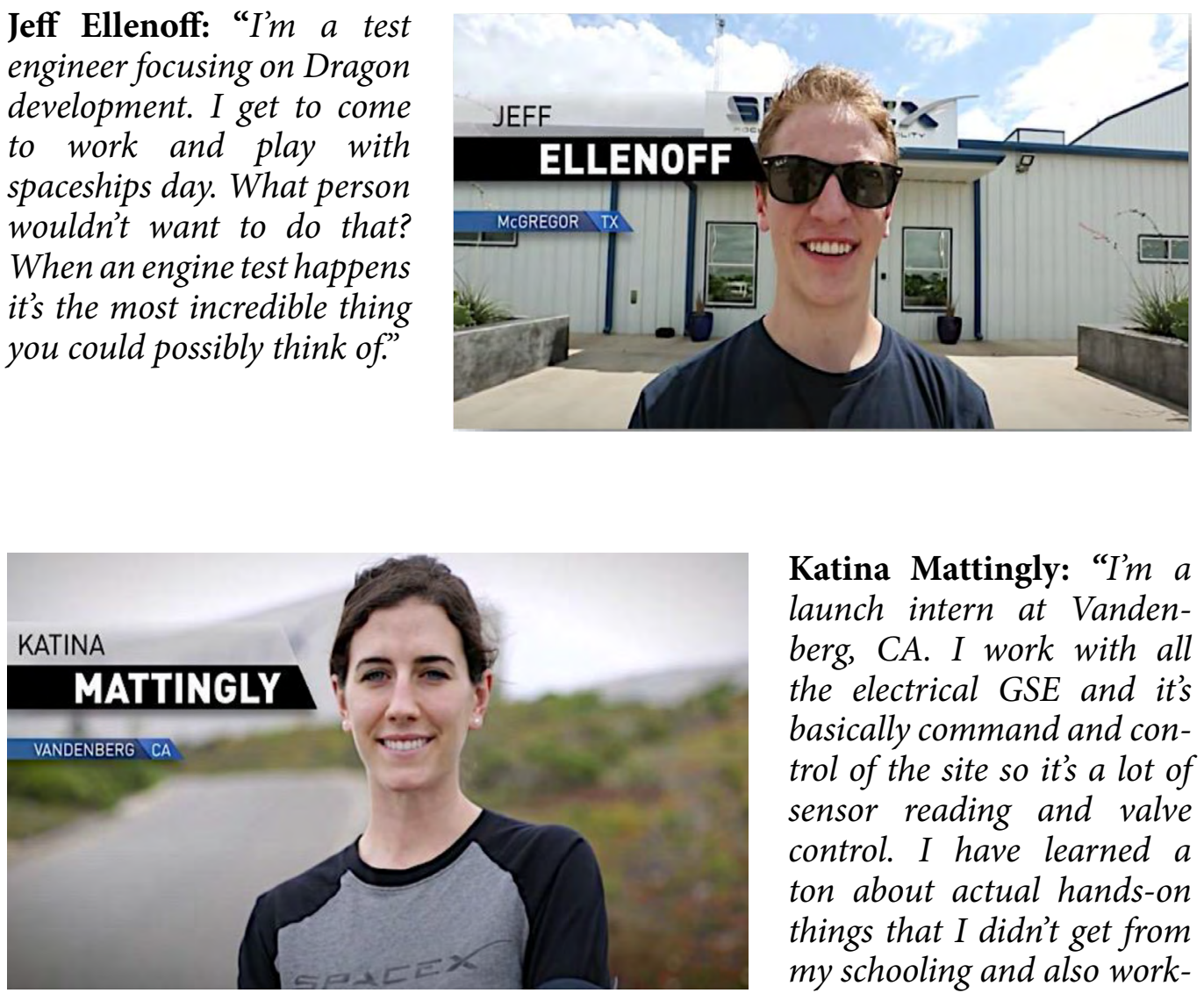

Katina Mattingly: "I'm $a$ launch intern at Vandenberg, CA. I work with all the electrical GSE and it's basically command and control of the site so it's a lot of sensor reading and valve control. I have learned a ton about actual hands-on things that I didn't get from my schooling and also working with technicians. I work with technicians every day. My view everyday driving into work is the ocean ... and Tejas Parekh: "I am a launch intern at Cape Canaveral. it's a beautiful view."

Walking the launch pad is cra$z y$ ! There are so many different aspects to it and you get to do absolutely everything here. So I get to fulfill roles as a design engineer working at my desk with modeling and analysis, and then the next day I work as a build engineer ordering materials and sending drawings to technicians. I'd recommend this location to anybody-especially due to the

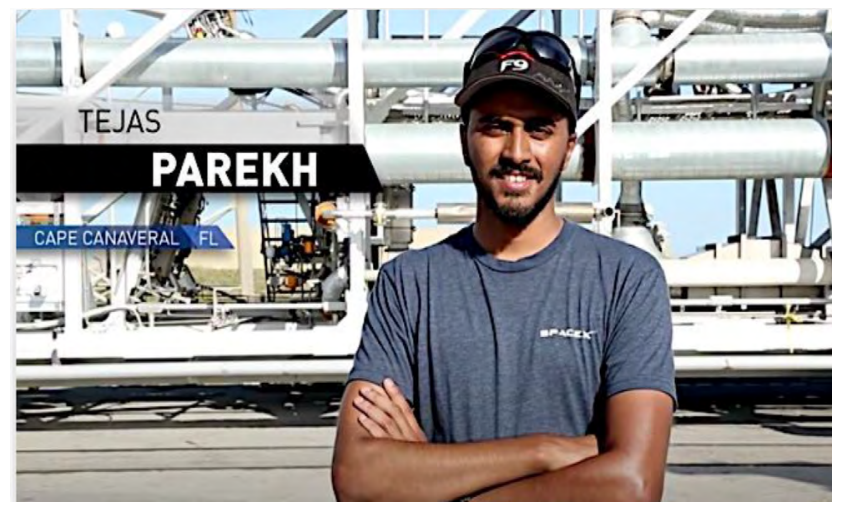
fact that you get to act as an operations engineer and actually launch a rocket!" 


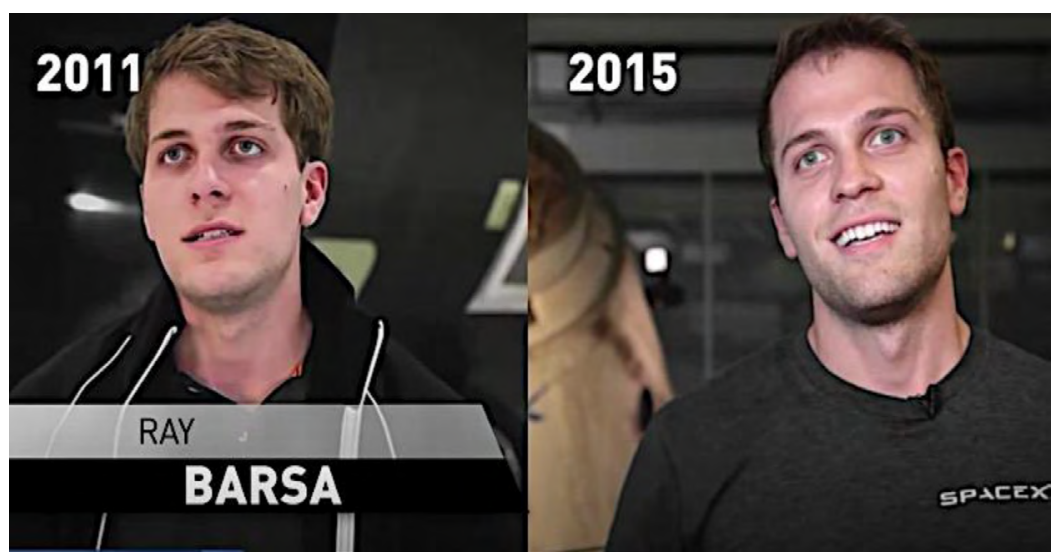

Ray Barsa (former Intern): "SpaceX is a great place for interns to find full-time jobs. By the end of my internship, I knew all of these processes and approaches that SpaceX took to manufacturing, so by the end of it, I could really kind of take whatever composite assembly was thrown at me and bring it to life here in the factory."

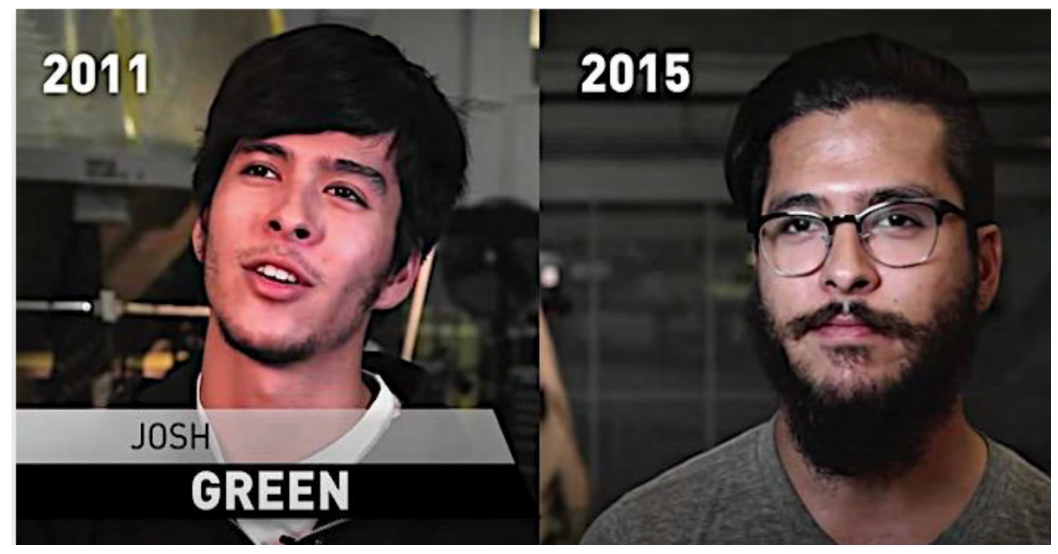

Josh Green (former Intern): "Mentors here are infinite. You have you're "starting out" mentor for your engineering internship and you're in your group or department and they will definitely feed down the requirements that are expected of you, but as you step out onto that work floor and start getting your hands dirty, you have everyone from recent grads all the way to 30- or 40-year veterans. Overall, the SpaceX internship program is certainly a great training regiment for full time work here or anywhere else in your engineering career." 


\section{Internship Positions}

$\mathrm{B}$ elow is a list of all of the available team internship positions and their descriptions at SpaceX:

Avionics: Designs, develops, manufactures, tests, analyzes and integrates all electronic hardware. This includes but is not limited to: power conversion units, analog and digital circuit boards, FPGA's, communication system units and firmware as well as enclosure and wire harness development.

Build Reliability: Ensures quality production of assemblies and piece parts that flow into the production of the vehicle and proactively improve the vehicle reliability. This group develops standard tools, processes, methods, design adjustments and requirements to ensure production reliability.

\section{Customer Operations And Integration:} Serves as the main interface between technical teams and customers to ensure our missions are successful and timely. This group encompasses the Space Operations team, which focuses on revolutionizing spaceflight operations for cargo and crew Dragon missions, as well as future company missions. There are roles in product management, mission management, mission engineering and proposal development.

Flight Reliability: Reviews and certifies the vehicle's test and flight readiness. This team works to maintain safe, reliable practices during operations and to bridge operational and design challenges between test and launch. Flight Reliability interacts with the engineering, production, test and launch teams from the planning stage all the way to launch for the purpose of reviewing the vehicle configuration and status.

Launch Engineering: Fly, recover, fly again. The Launch team works at our Florida launch sites, as well as Hawthorne headquarters on our Falcon 9, Falcon Heavy and Starship launch vehicles. Teams within this organization include but are not limited to: Ground Operations, Payload \& Vehicle Integration, Recovery Engineering, Fleet Management, Launch Site Systems and Development Test.

Materials Engineering: Creates materials solutions to expand the capabilities of current vehicles and to push design boundaries for our future ones. They cover a wide range of materials disciplines from alloy development, large scale composite structures, additive manufacturing and traditional aerospace materials. This group's work supports new designs, enabling re-usability of rockets and materials research focused on interplanetary travel.

Production: Leveraging best-practices from a wide variety of industries, SpaceX aims to scale its production rate beyond that of any other launch company in the world. The Production group provides hands-on experience in a fast-paced environment with cutting edge technology. This group includes but is not limited to: Launch Vehicle and Spacecraft Assembly, Tooling Engineering, Industrial Engineering, Automation \& Controls and Manufacturing Engineering. 
Propulsion: Creates advanced rocket and spacecraft propulsion systems. This team designs, analyzes, builds and tests engines that will one day take humans to Mars. SpaceX currently builds more rocket engines than any other organization in the country. Furthermore, the design and performance parameters of SpaceX engines are notably recognized throughout the industry.

Purchasing: The SpaceX purchasing team is responsible for ensuring lowest product cost and risk through supplier management, strategic negotiations; spend analysis and continuous process improvement. An intern joining this team would expect to gain first-hand experience analyzing supplier and spend data, communicating with suppliers, purchasing direct and/or indirect goods or services, and support of various projects like creating and implementing new processes.

Software: Develops software used to design, develop, test and launch rockets, spacecraft and satellites. In addition to embedded software engineering, they also do simulations, distributed data management and develop analysis tools used in preparation for a launch. Their problem domains span embedded, fault tolerant, flight control, web, mobile, cloud and big data computing. The products that they develop run on low-power space computing platforms, mobile devices, desktop systems and in data centers.

Supply Chain: Improves and develops the business processes that enable SpaceX to design, build, launch and reuse the most advanced rockets in the world. Interns in this group will help innovate and improve efficiencies to ensure that the Supply Chain team is continuously evolving to meet its internal customer demands and to achieve SpaceX's overall mission of sending humans to Mars.

Test Operations: SpaceX tests every engine, component and stage for development and flight at a 4,000-acre state-ofthe-art rocket development facility in McGregor, Texas. Interns will receive the opportunity to take ownership of projects related to the systems and hardware used to prove out the next generation of American rockets.

Vehicle Engineering: Designs, develops and qualifies hardware on all vehicles. This group partners with engineering and production teams to create innovative, mass-efficient vehicle and spacecraft structures. This group includes but is not limited to: propulsion components, structures engineering, in-space propulsion, integration \& test, vehicle analysis, thermal \& fluid analysis, life support systems and guidance navigation \& control.

\section{What Qualifications Does SpaceX Look for in an Internship Candidate?}

Basic Qualifications:

- Must be currently enrolled at an accredited four-year university or college

- Business operations or software applicants must be currently enrolled 
at an accredited university or college or within 6 month post-graduation

Preferred Qualifications:

- GPA of 3.5 or higher

- Strong interpersonal skills and ability to work effectively in a team environment, accomplishing tasks with limited resources at a rapid pace

- Intermediate skill level using Windows Operations Systems

- Intermediate skill level using Microsoft Office (Word, Excel, PowerPoint, Outlook)

- Technical roles: Hands-on experience through engineering project teams, lab research, or through a prior relevant internship or work experience

- Business operations roles: Prior relevant internship or work experience

What are the basic and preferred qualifications to apply for the Associate Engineer Program?

Basic Qualifications:

- Completed a bachelor's degree from an accredited four-year university within the past 6 months by start of employment or currently enrolled in a graduate program

Preferred Skills and Experience:

- GPA of 3.5 or higher

- Strong interpersonal skills and ability to work effectively in a team environment, accomplishing tasks with limited resources at a rapid pace
- Intermediate skill level using Windows Operations Systems

- Intermediate skill level using Microsoft Office (Word, Excel, PowerPoint, Outlook)

- Hands-on experience through lab research, engineering project teams, or through a prior relevant internship or work experience

If your resume and credentials yield you an interview, below are examples of questions SpaceX interviewers have asked prospective SpaceX interns to answer.

The hiring process typically consists of two in-depth phone interviews, during which intern candidates have to answer questions like the following (Walters, 2015):

"What are composites?"

"What is the size of an integer on a 32bit system?"

"Let's say you have a variable 'var' assigned to be '2'. What will display if you print 'var++'? If you print '++var' on the next line, what will be displayed? What is the final value of 'var'?"

"What is a null pointer?"

"If you have a large, heavy object moving very, very fast, how do you safely slow it down?"

\section{Conclusion}

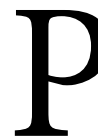
rior to COVID-19, the Class of 2020 could anticipate a strong job market upon graduation. This has dramatically changed as we head into a recession and high unem- 
ployment rates. This tragic experience will, for better or for worse, alter several aspects of our lives going forward.

It's important that college students strongly consider degree programs leading to job opportunities marked as "high need" and acquire skills that will be essential for transitioning the economy from its current state to one that is driven by digital interaction. For example, the requirement to self-isolate has forced innovation upon both industries and educational institutions that have been slow to adopt. Those who have embraced technological advancements will fare much better than their non-technical counterparts. We are already beginning to see this "survival of the fittest" fiercely play out before our eyes, as business that are adapting to the new paradigm are demonstrating resilience, while those that remain reliant on traditional business processes are in rapid decline.

Thus, not all college students will experience the negative effects of the recession upon graduation. There will be more job opportunities (and less competition) for college students in STEM programs and especially those who will seek a space-related occupation--which are, and will continue to be, in demand.

Albeit SpaceX is certainly not the only the only company in the space industry offering the added benefit of internships to college students, in terms of future job security, it's apparent SpaceX is poised for growth. And where there's growth, therein lies opportunity.

For more information on the SpaceX Internship https://www.spacex.com/ internships

\section{References}

Angeles, D. and Vilorio, D. (November 2016). "Space careers: A universe of options," Career Outlook, U.S. Bureau of Labor Statistics. Retrieved from https:// www.bls.gov/careeroutlook/2016/ article/careers-in-space.htm

Cooke, K. (April 20, 2020). "SpaceX Satellite Internet: What you Need to Know about Starlink." SatelliteInternet. Retrieved from https://www.satelliteinternet.com/providers/starlink/

Mack, E. (2020, April 1). “Coronavirus pushes SpaceX competitor OneWeb into bankruptcy". CNET. Retrieved from https://www.cnet.com/news/corona virus-pushes-spacex-competitor-oneweb-into-bankruptcy/

Koren, M. (April 13, 2020). "The Mission NASA Doesn't Want to Postpone." The Atlantic. Retrieved from https:// www.theatlantic.com/science/archive /2020/04/spacex-nasa-coronavirus-as tronauts/609871/

Mazumdar, T. (March, 26, 2020). "Coronavirus Update: SpaceX Is Creating Hand Sanitizer, Face Shields To Donate Amid COVID-19 Pandemic." IBTimes. Retrieved from https://www.ibtimes. com/coronavirus-update-spacex-cre ating-hand-sanitizer-face-shields-do nate-amid-covid-19-2947073.

Morgan Stanley. (July 2, 2019). "Space: Investing in the Final Frontier." Retrieved from_https://www.morganstan ley.com/ideas/investing-in-space 
NSR. (June, 2019). Global Satellite Ca- Walters, N. (October, 14, 2015). "11 pacity Supply and Demand, $16^{\text {th }}$ Edi- tough interview questions you may have tion. Northern Sky Research. Re- to answer ifyouwant to intern at SpaceX". trieved from https://www.nsr.com/re Business Insider. Retrieved from https:// search/global-satellite-capacity-sup www.businessinsider.com/11-toughply-demand-16th-edition/ spacex-interview-questions-internsget-2015-10\#describe-the-design-

Palerm, L. (August 28, 2019). "WILL process-of-a-series-of-pipes-to-beLEOS CREATE A TRILLION-DOL- used-in-a-rapid-fueling-system-forLAR INDUSTRY?” Northern Sky Re- a-liquid-propellant-rocket-enginesearch, Retrieved from https://www. be-sure-to-include-which-equationsnsr.com/will-leos-create-a-trillion-dol would-be-best-for-the-case-at-handlar-industry/ for-fluid-pressure-calculations-andstructural-considerations-11 